\title{
Using Electronic Interaction as an Educational Support Tool in Higher Education: Students' Perception on using M-Learning and the Lecturers' Reflections
}

\author{
${ }^{*}$ Hannelie Van Rooyen, Walter Matli \\ Vaal University of Technology, South Africa \\ *hannelie@vut.ac.za
}

\begin{abstract}
Teaching and learning in higher education must be transformed to give support to the new generation of "digital native" students. Students depend on their mobile phones to do almost everything. The purpose of this research is to determine the perception of students on using mobile phones as an educational supporting tool and discusses higher education challenges and benefits of using electronic communication as an educational supporting tool. Most students use their mobile phones daily and they enjoy the technology that mobile phones offer them. The research was conducted at Vaal University of Technology (VUT) Ekurhuleni Campus. The findings of the research indicate that electronic communication will have a positive impact. Currently, more students have access to mobile phones than computers. Mobile phones can thus be considered an enabling technology in supporting learning and teaching. This research has provided a basis for VUT and other higher learning institutions' academic leaders to start the discussion and the possibility of introducing the use of m-learning in adult education. With the increasing use of electronic communication, the traditional teaching approach and interaction between the lecturer and student(s) is changing and the adoption of friendly electronic communication has become more important.
\end{abstract}

Keywords: Interaction, m-learning, educational support, higher education, mobile phones

\section{Introduction}

Over the last twenty years, universities are increasingly using technology to reorganise how to learn, teach, and communicate (Siemens, 2004). Information and Communication Technology (ICT) is regarded as the most often utilised teaching strategy, learning and assessment tool in higher education institutions. The current generation of students enrolled in higher education institutions has more access to digital technology than ever before (Duncan-Hawell, 2007). Academic staff in higher education institutions is faced with the challenge of educating this "digital native" generation of students, who find technology more appealing. The education industry, like other industries, is reshaped by the power of technology (AlFahad, 2009). Using mobile technology will in turn make our students competitive in the market place, based on the dominance of technology in modern society. Importantly, students will find learning using mobile technology more interesting than using the same old method of teaching without any enhancement. Mobile technology is making drastic changes to the world we live in presently; with mobile technology people are able to do banking and shopping effortlessly, at any time and any place. It is time that higher education institutions develop methods of incorporating the power of mobile technology into teaching and learning. Mobile phones provide users with the ability to communicate (send and receive) messages in a form of text, multimedia text and various texting applications (Resources, 2006). Lecturers are moving from a teacher-centred learning approach to student-centred learning approach; higher education learning is moving away from the ideology that the lecturer is an expert of the module, to the lecturer portrait as the facilitator of learning. M-learning as educational supporting tool will ultimately benefit the lecturers, students and the institution. With m-learning students have an extra tool that support their learning and subsequently this may assist to improve their pass rate.

Higher education lecturers must use a variety of electronic communication to support learning outside the class contact sessions (formal), while students are off-campus (informal) or on campus, but not during the contact session (semi-formal). The most critical challenge for lecturers in higher education is teaching students who are not fully prepared for higher education and these students are known as incredibly sophisticated and technology wise (Schroer, 2013). The institutions of higher education have to make available an environment that is friendly, that will support students' learning, and in addition basic "conditions, opportunities and expectations" (Kift et al., 2010; Coates, 2005). These basic components will play a critical role in the students' learning and succession, and furthermore the friendly 
environment will contribute to ease first year students as it is their first time familiarizing themselves with the higher education environment. Higher education institutions have crossed the threshold into a new dawn where the quality of students plays an important role (Kuh, 2007). Most of the higher education institutions in South Arica, like elsewhere, are faced with the challenge of teaching students that are not fully prepared for higher education, and the other problem that has not been fully addressed is the challenge of cross university integration. Most performing universities have kept their entry level point system reasonably high so that they can attract better performing students.

In the past decade or so higher education has had students equipped with some sort of technology skills. Precisely from their social network applications and mobile technology usage, this technology that students are fully equipped with can provide opportunities and challenges if used for learning by higher education (Nicholson, Macleod \& Haywood, 2005). Recently there has been an increasing interest in research focusing on students' perception and experience of using technologies as a tool in learning such as e-learning and m-learning, by researchers such as (Duncan-Hawell, 2007; Brown, 2005; Matli, Conradie \& Sibiya, 2013). The researcher Duncan-Hawell (2007) indicates that there has been an increase in digital technology use by the current students in higher education institutions, and (Matli et al., 2013) give an indication that students are already using mobile technologies such as Social media application. The students from the Net generation are familiar with and use numerous technologies such as Social network applications in their lives generally and in their academic studies (Tapscott, 2009; Ramau, Hosein \& Jones, 2010). The findings by Tapscott (2009) compliment the views by (Oblinger \& Oblinger, 2005), and the researchers state that students from the Net generation are familiar with using technology from both their basic schooling and at home before enrolling in higher education.

Mobile Technology in Education: The researcher concur with Traxler (2009) that it is difficult for someone to define m-learning as it is emerging and continuously affected by the ever changing and enhancement of mobile technology worldwide. M-learning has gained a lot of interest for some time by researchers especially those in the field of education, but there are numerous attributes related to mlearning that have not been fully dealt with in their research findings (Goh \& Kinshuk, 2006). The usage of technology in the education sector (e-learning) provides room to benefit teaching and learning especially in higher education institutions (UNESCO Institute for statistics, 2009). M-learning plays a crucial role in supporting formal learning (Class contact session), as it extends learning to be successful in informal and semi-formal (beyond class contact sessions) settings (Winters, 2006). In a developing country like South Africa, it is estimated that sixty-five present of mobile phone users are proficient in accessing mobile internet (World Wide Worx, 2010). These results give an indication that there are a continuously growing number of people accessing internet from their mobile devices. This is precisely due to the fact that it is cheaper to access the internet from a mobile phone device than from a desktop or other device. The growing usage of smart phone devices has granted higher education institution students the opportunity to access learning material from their smart phone devices. Previously, students accessed their learning material from their desktops and laptops, now smart mobile phone devices have made it possible for users to access learning material from their mobile phones. This is due to the fact that smart mobile phone devices have powerful functions and have easy internet access, like computers (Matli et al., 2013). There are numerous challenges that affect the education system in South Africa and like elsewhere; some common challenges include lack of textbooks, computers with internet access and poor academic performance by students (Walton, 2009). Mobile technology devices' use has the potential to help in eradicating some of these challenges.

\section{Higher Education and Electronic Communication}

Higher education institutions need to decisively address what the students' needs are, as part of supporting teaching and learning. Higher education institutions must individually do their own feasibility studies, because what may work for VUT Ekurhuleni campus may not successfully work for University of Venda in the Limpopo province. This is because of the different geographical demarcation of the Universities. The success of mobile application will depend on the mobility of student and mobility of learning (Traxler, 2007). Academic leaders need to cater for students that come from townships and rural areas and first time users of technologies used in higher education. Higher education institutions need a better ICT infrastructure that will support the usage of technology. With a good technology infrastructure, facilitators can combine some of the learning theories such as constructivism, cognitivism and add an element of connectivism. While other learning theories can complement each other, connectivism is viewed as an independent learning framework (Alley, 2008). Over the past decade higher education 
teaching has seen cultural change moving from content-based to student-centred approach (Robertson, 2001).To promote student-centred learning the lecturer needs to engage with students for that subject or course and reach an agreement on how they would prefer electronic communication interaction to be conducted. Recent research indicates that to get students to participate in learning, higher education institutions need to identify the level of student involvement (Strydom et al., 2010). It is important for the lecturer to involve students because once students feel that their input contributions were considered then they tend to participate more.

University students spend most of their time online, using a variety of electronic communication such as social media to chat with people they know and people they do not know personally in some instances. This generation of students enjoys chatting online more than being in the classroom. Because there is no face-to-face intimidation, even the shy students that totally do not participate during class contact sessions tend to participate in electronic communication. Higher education institutions have to take the advantage of using mobile technology devices; students will not require training as most of them are already familiar with using mobile technology devices. Higher education institutions must use what is fully available to students and not use educational supporting tools that will require students to spend money to access those tools. One of the fundamental problems in higher education institutions noticed by the researcher is the use of Learning Management system (LMS) to support teaching and learning for under-prepared students. Most students become more vulnerable when they have to cope with the standard level of higher education workload and at the same time they need to understand and use LMS such as Sakai and Blackboard. The writer recommends that higher education institutions should use tools that students are already familiar with in addition to LMS, tools that they will not require training for in their usage, especially for the first year students. This may reduce the failure-rate of these unprepared students.

Figure 1: Electronic communication for education support

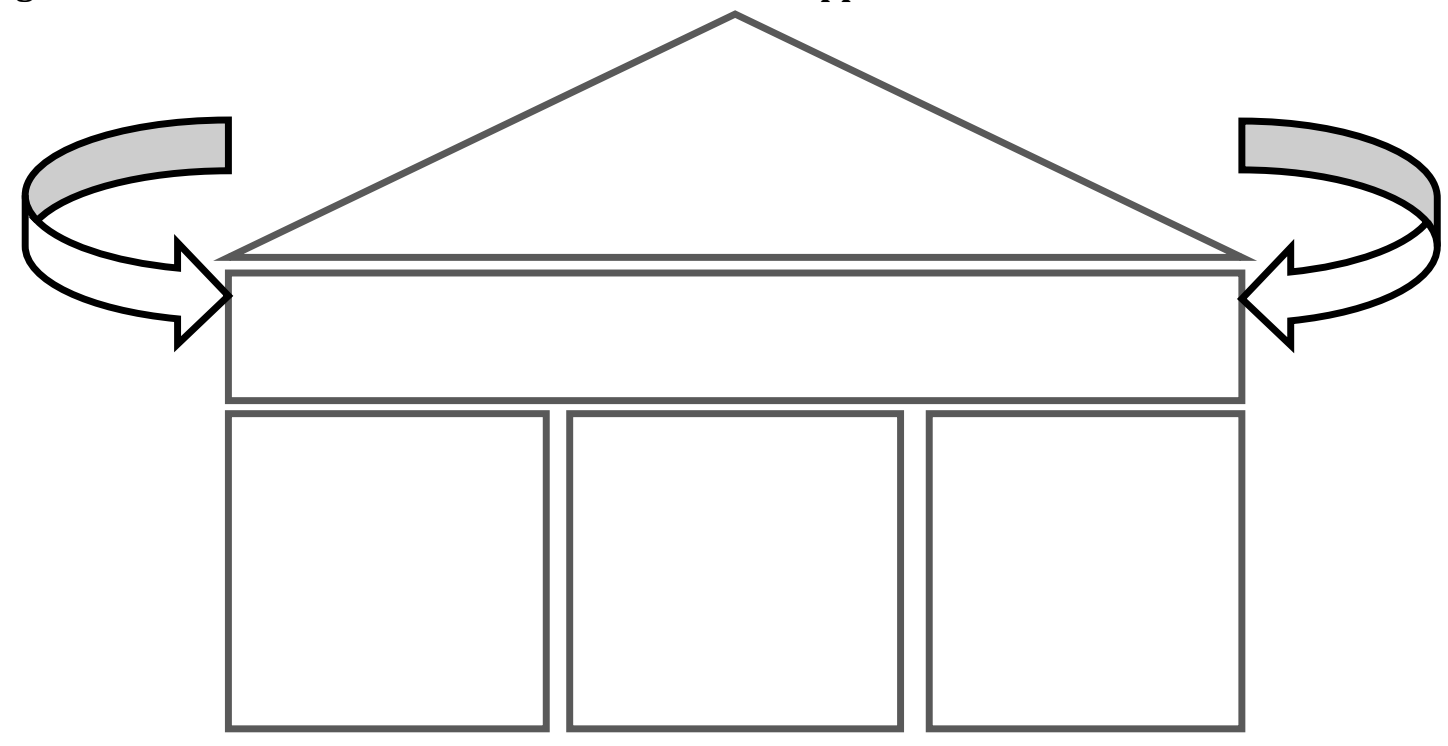

The researcher created the above framework which he assumes can play a significant role when higher education institutions want to use electronic communication for educational support. E-Learning platforms are extremely powerful in the way they appeal to the natural inquisitive nature of higher education students.

M-Learning: the use of mobile phones is one of the most exciting innovations in the twenty-first century; they allow students to access information online and because they are portable students can take them everywhere they go. Mobile phones afford users with a new type of computer-mediated communication (Ling 2008).

Social media: higher education students spend most of their time on electronic communication, mostly social media applications. This generation of students described as generation y by Schroer (2013), currently in higher education institutions enjoys chatting on electronic communication in the classroom during contact sessions. Not much training will be needed as students are already using the platform.

Bring Your Own Device (BYOD): this is changing the role of lecturers in higher education and it also gives lecturers time to focus on research and innovation. At the pace which technology is rapidly changing and 
affecting our day-to-day activities, in few years every student will be bringing their own devices such as iPads, laptops, and smart phones among others, to class. Currently the researcher has noted that some students have started bringing their own devices to the classroom but in small margins numbers? These devices enable collaboration facilitated learning.

Although electronic communication has the potential to be used as an educational supporting tool, there are also some issues that need to be dealt with. Some of these critical issues include deploying a mobile device policy management tool, implementing an infrastructure to secure data on student-owned devices and the critical challenge being expensive data connectivity.

Purpose \& Necessity of the Research: VUT Ekurhuleni has experienced an increase in the number of unprepared first year students from basic education to higher education, just like any other higher education institution or training centres, most of which are familiar with mobile devices technology. The purpose of this study is to determine students' perspective on using m-learning as a supporting tool in teaching and learning. Effective learning is important to the creditability of any academic institution. The study therefore aims at discussing the paradigm shift that has taken place in teaching and learning in higher education institutions, as manifested through the change from face-to-face learning (i.e. instructivism) to a more blended learning (b-learning) environment. The researcher's objective for this research is to make a prediction of how students will be taught in future, this will give an indication of where higher education is heading and this may assist leaders in academic spheres to plan for the future.

\section{Methodology}

The researcher reviewed literature from a variety of journals, books and other online materials to learn and justify the current information on mobile technology and electronic communication in higher education. This variety of sources was also used by the researcher to analyse and identify concepts for this research. This contributed in assisting the researcher to gain a wider insight of the topic being researched. Higher education researchers are continuously evoked and attracted to conduct research on first year students' experience enrolling in higher education institutions (Kift, Nelson \& Clarke, 2010). This is mainly caused by the different generations of students enrolling in higher education; the current generation is more techno-wise than previous generations. The researcher used the method of interviews to collect data with 20 students, of which 15 were males and 5 were females. During the interviews the researcher used a tape recorder which assisted the researcher to focus on the interview and not write down students' responses while conducting interviews. All the respondents were students registered for the Information Technology (I.T) bridging course known as Bootcamp, which runs for one semester. Students on the Bootcamp programme are students that did not meet the minimum requirement to enrol for IT national diploma. The respondents were registered students at VUT Ekurhuleni campus. The demographics of respondents are demonstrated in the table below (Table 1). This research was limited to VUT Ekurhuleni Bootcamp students only due to the fact that interviews are time consuming; the researcher is a lecturer based at VUT Ekurhuleni campus and could not afford to conduct the same research on other campuses of VUT because of demarcation of other campuses and financial background.

Figure2: Ekurhuleni Metropolitan map where VUT Ekurhuleni is located (adapted from Gauteng Map Search (2008:1))

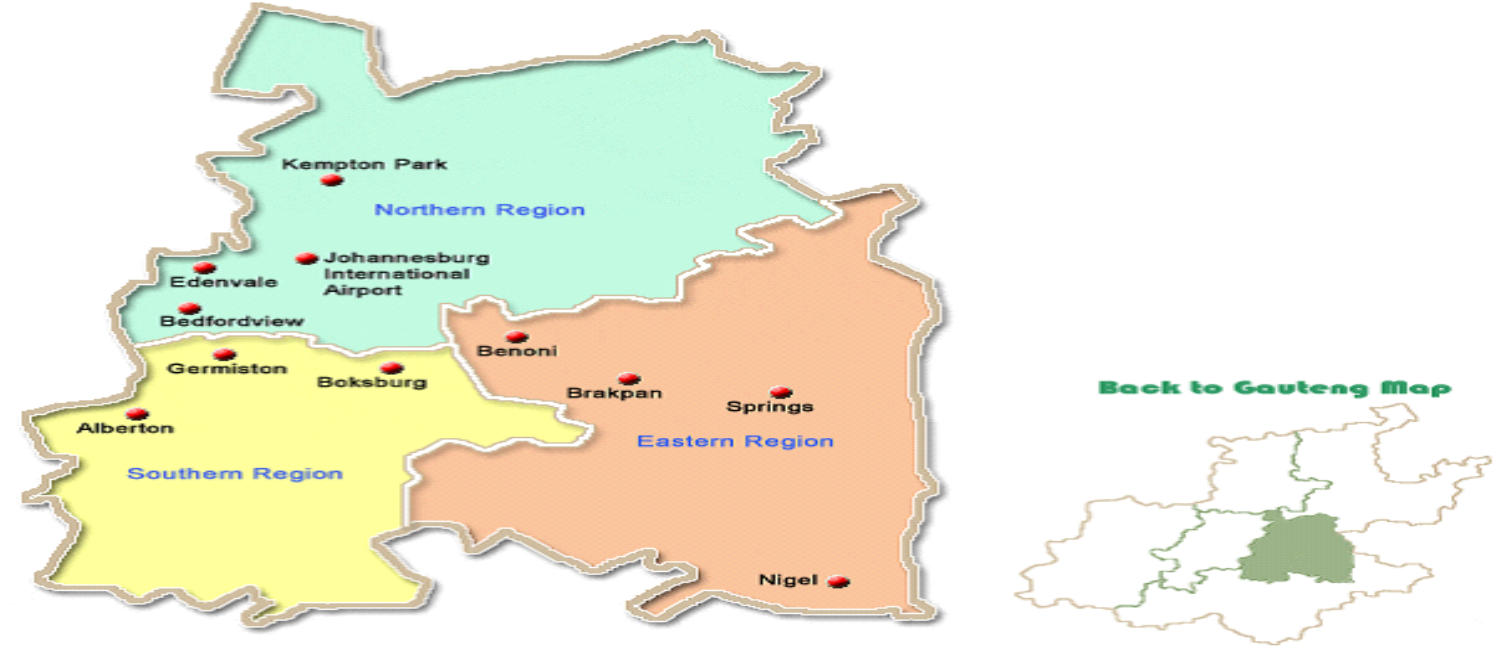


Case Study: Vaal University of Technology Ekurhuleni Campus: The VUT Ekurhuleni campus was established 19 years ago in 1995. The campus currently has a population of an estimated 1300 students registered both full-time and part-time. VUT Ekurhuleni campus is a satellite campus of the main VUT in Vanderbijlpark. Located in the industrial hub of the Ekurhuleni Metropolitan municipality, the campus currently offers the following courses: Information Technology National Diploma and BTech degrees, and the following National Diplomas in Tourism, Auditing, Cost management and Marketing. The VUT Ekurhuleni campus aims to expand the courses they offer once they expand the infrastructure or relocate the campus. Ekurhuleni Metropolitan is one of the three metropolitan municipalities found in the province of Gauteng and it is the only province with three metropolitan municipalities in the country. VUT Ekurhuleni is located in Kempton Park which is less than 10km from the biggest African gateway (OR Tambo Airport) which is in the province of Gauteng, famously known as the province of gold, South Africa. The population of this province has different races and people with different beliefs. Most people come from all corners of the world to Gauteng province because of opportunities that are available in this province.

\section{Results}

Table 1: Provinces and countries of respondent's secondary school

\begin{tabular}{ll}
\hline South African Province & $\begin{array}{l}\text { Demarcation } \\
\text { Percentage }\end{array}$ \\
\hline Gauteng & $55 \%$ \\
Limpopo & $30 \%$ \\
Kwazulu Natal & $5 \%$
\end{tabular}

International

Angola $\quad 10 \%$

Students' secondary school demarcation: The table above indicates that not only South African students are registered in VUT Ekurhuleni Bootcamp, but also people from other African countries prefer to send their children to get the best education in the province that is full of opportunities. The table above indicates that there are a reasonable number of students coming from other provinces and countries to study at VUT Ekurhuleni in the province of Gauteng. Gauteng is a too diverse province in South Africa compared to the other eight provinces. The researcher would like to acknowledge that this research does not represent the complexity representative of the province nor the metropolitan municipality of Ekurhuleni population. Therefore, the research only aims to get students' opinions and thoughts on using electronic interaction as a supporting tool in higher education.

Perception of Using Mobile Devices to Support Learning: Two-thirds of the respondents indicated that mobile applications have a major role to play in supporting teaching and learning. Comments from respondents indicate that students believe mobile applications can be used successfully. Usage of technology that is widely available to students will reduce the cost in communication between students and facilitators (Gilbert et al. 2007). Technology has the potential to be used as a supporting tool and has been found to have positive impact on supporting teaching and learning (Simuth \& Sarmany-Schuller 2012). Some remarks:

"It is actually very helpful because it is always here, it come in very handy"

"It is a quick way and saves time and money. And if you want to make announcement it will be a good way to use messaging applications, people will get the information quickly and not come in person"

Mobile application has a significant impact on supporting teaching and learning in higher education. Research respondents were students completing their first year at VUT Ekurhuleni from secondary schools. In total, $40 \%$ of the participants were from private secondary schools and $60 \%$ from public secondary schools. A significant number of respondents agree that mobile applications can play a major role in supporting teaching and learning in higher education. Mobile applications give opportunities for students to not only consume knowledge, but also produce knowledge, related to the learning theories of constructivism and connectivism. Learning is critical for successful students, enabling them develop an in depth understanding of the academic discipline in which they are qualifying. Higher education also plays a key role to facilitate students' success. But ultimately students' success depends on the individual 
student; there is only so much that a facilitator can do to assist a student to pass. Importantly, there must be willingness and interest from the student to want to successfully learn, thus the motivation. Traditional learning theories are still appropriate, even in the digital era, since the way students learn does not change, only the technologies that are utilised. It is important that academics understand the world that students are living in, i.e. the digital era.

How often do respondents use the mobile applications? All the students that took part in the research indicated that they use mobile applications daily. This is because they use the applications to communicate at a low cost. They use messaging applications also to stay in touch with the world out there.

"Practically every day"

"Every 20 minutes"

"Full time"

Connectivism at VUT Ekurhuleni Campus: According to the research results, the use of smartphones is growing at a higher level than those of non-smartphones. This indicates that there is an evolution in users, moving from non-smartphones to smartphones. From the findings, $85 \%$ of respondents use smartphones while 15\% uses non-smartphones. With technology rapidly changing and the reduced price of smartphones, it is likely that the $85 \%$ use of smartphones will increase to a $100 \%$. Furthermore, results also indicate that mobile phones can be utilised effectively to support teaching and learning at VUT Ekurhuleni, since mobile phones are widely available to students. The introduction of mobile applications can play a supportive role in bridging the gap between formal and informal learning in higher education (Wagner \& Wilson, 2005). Connectivity is a major problem for VUT Ekurhuleni campus, with few internet labs that have internet connection. This has resulted in students turning towards the use of alternative devices to access information from the Internet, including mobile phones. Most students have access to mobile phones and subsequently access Internet connection from their mobile phones. Results indicate that $70 \%$ of respondents access the Internet from their mobile phones and $5 \%$ use computers to access the Internet.

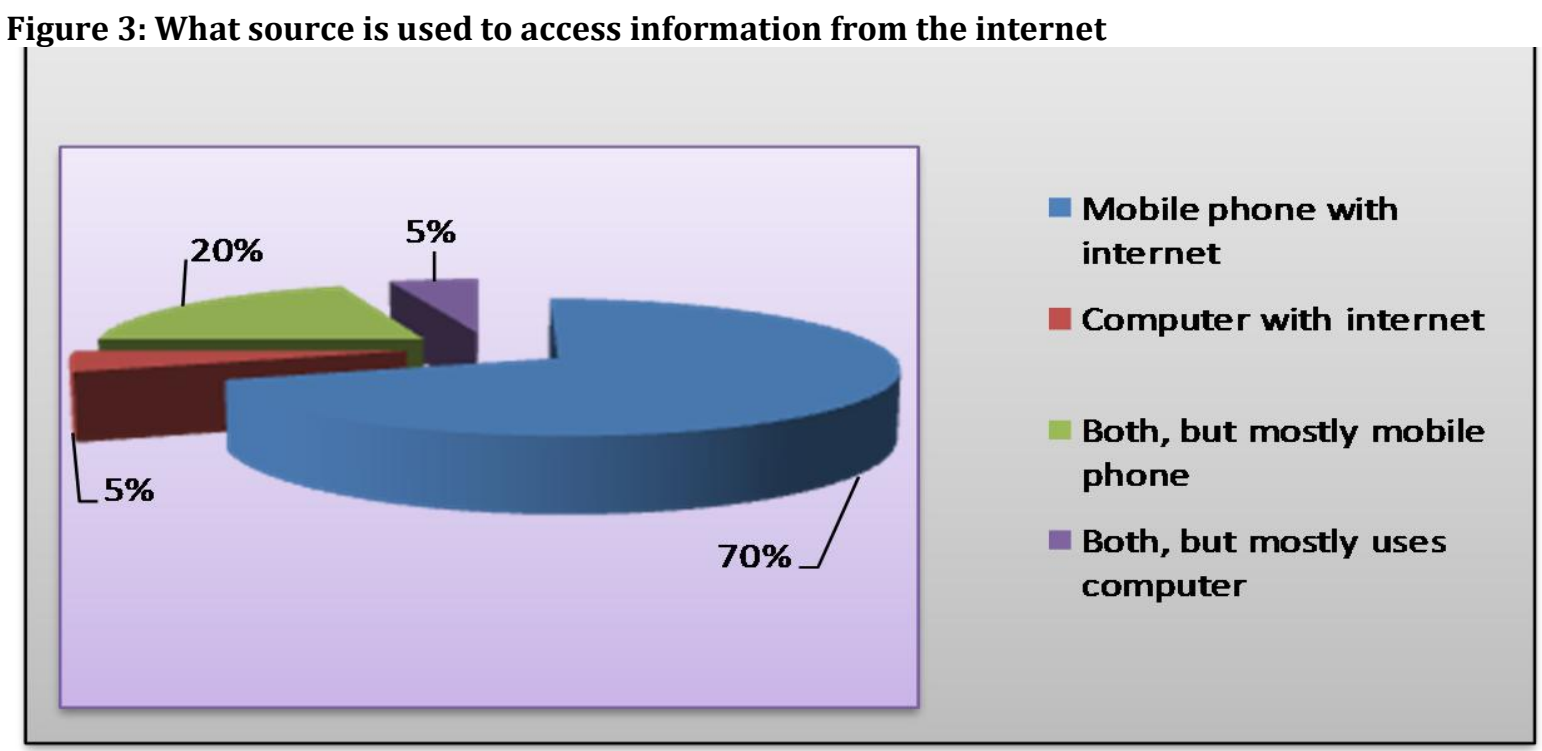

VUT Ekurhuleni campus needs to use mobile applications that are available to students. One of the most widely used applications is Facebook. This is no surprise, since all participants mention Facebook as one of the applications they use the most and most regularly. There are a number of applications that have been used by higher education in mobile language, including emails (Torri-Williams 2004).

Mobile Applications used by Students: The current generation of young people use a variety of different types of Social media applications (Green \& Hannon 2007). Research carried out by researchers (Duncan-Hawell 2007; Brown 2005; Matli, Conradie \& Sibiya 2013) gives an indication that the use of technology in higher education is growing in popularity. There is a lot of assumption about who uses these technologies and how frequently they are used. According to Duff (2013) Facebook is the most 
used application with 9.4 million users in South Africa, and interestingly enough $87 \%$ access Facebook from their mobile phones. Duff (2013) further reports that the second most used application is Mxit with 7.4 million users; I concur with these findings by Duff (2013) as in table 2 findings from my research indicate that Facebook was the most used by students followed by Mxit from participants. From table 2 the second most used application is Whatsapp with $70 \%$ and Mxit at third position with $50 \%$.

Table 2: Mobile applications used by respondents

\begin{tabular}{ll}
\hline Application & Usage \\
\hline Facebook & $100 \%$ \\
Mxit & $50 \%$ \\
Twitter & $30 \%$ \\
2go & $15 \%$ \\
BBM & $40 \%$ \\
MySpace & $5 \%$ \\
Whatsapp & $70 \%$ \\
Instagram & $5 \%$ \\
\hline
\end{tabular}

Challenges of Using Mobile Applications: The respondents indicated a few challenges of using mobile application as a supporting tool for teaching and learning. Some of the challenges include the issue of security, which needs to be measured to ensure the confidence of users. Addictiveness was also one of the challenges discussed, which has both a negative and positive influence. On the positive side, it assists students to gain valuable knowledge. On the negative side, addictiveness can result in students not concentrating in class, but focusing on social mobile applications. Although there are positive factors in the use of mobile technologies in education, there are still practical concerns that need to be addressed (Granic et al., 2009).

"Yes, not everyone will have access to internet; it might be a problem if we decide to use it academically"

"No, none that I can think of"

"The security issue, basically"

"They can be addictive"

Researcher's Reflections: Challenges of using Electronic Communication: The researcher's discussion is from the position of a novice lecturer who has an interest in e-learning. It has been realised that most researchers, especially novice researchers, have conducted research on using electronic communication such as social media (Facebook, Blog, etc.) just to name but a few. In all the five conferences attended on e-learning and the literature reviewed, they focus more on the benefits of using electronic communication and fewer touch on the challenges of using electronic communication. It was hoped that since most of the researchers on e-learning are academic staff, they will also discuss the challenges they have encountered as lecturers from students. This researcher concurs with other researchers just like in recent publications; electronic communication has a wonderful opportunity to position itself as a supportive tool of learning between lecturer and students. But there are challenges that in most cases are not reported by researchers. While using a social media application as a supporting tool for one of the modules it was realised that some of the students were now and then asking personal questions such as " how is your weekend" although it was emphasised that the application was for educational support. It was decided not to respond to such texting, and some of those students started to withdraw from the application as they did not engage as before. It was assumed that by not answering their questions that were not pertaining to the module only pushed them away. In addition it was assumed that those students felt that by the researcher using social media with them for educational purpose they were invited to a friendship that did not exist.

The issue of connectivism is a huge issue in most of our societies. It was decided to use social media application as a supporting tool with them because they all had access to social media. Most higher education institutions use Learning Management System (LMS) as an educational supporting tool. But not every student in class could afford to timorously access the LMS from their mobile phones mostly Blackberry brand. The researcher did not want to add expenses to students; therefore it was opted to use a tool that was viable to communicate with them informally and semi-formally. Electronic communication such as social media applications are not easily managed and monitored like LMS tools. The major 
challenge of electronic communication between lecturer(s) and student(s) is that it is not monitored. Therefore, some students may push their personal agendas while the lecturer is only looking at utilising electronic communication to support students learning or vice-versa.

Researcher Reflections: Benefits of Using Electronic Communication: Lecturers are becoming more innovative and they are enhancing their methods of teaching, more especially that electronic communication is vastly available to students. The lecturer must use what is fully available to all students so that he does not end up disadvantaging other students, thus it is critical that all students have access to a tool that the lecturer intends to use. Recent research papers (Matli et al. 2013) indicate that the most electronic communication tool used by students is social media and most access social media from their mobile devices. It has over the past few years been observed that most students on this campus spent most of their time texting messages to each other on different electronic communication. As a novice lecturer who happens to be a "digital immigrant" you are often told to use the best accessible technology tools to support learning during class contact sessions (formal learning) or outside the class contact session (informal learning) especially in the department of Information Technology, and that there is a need to test students' understanding. Most of the novice lecturers then go all out and experiment with different electronic communication tools to support learning and hope that students' performance will improve, and increase the students' pass rates.

It was noticed that most of the students are often freer to engage with electronic communication than attending the class contact sessions (formal setting).As lecturer students' participation and how they express their thoughts could be evaluated. The researcher was able to facilitate students when using electronic communication and allowed students to share their thoughts with others. In one activity they were asked to define terms used before getting into depth of a chapter; some students' definitions were better than the lecturer's; so electronic communication made students to learn from themselves and the researcher also learned from them. Sometimes students found the lecturer's explanations more difficult than their peers', so allowing students to contribute their thoughts assisted other students to learn from each other. It was sensed that most students enjoyed using electronic communication because they did not feel intimidated either by their peers or their lecturer. Electronic communication allows students to think about their own thinking before texting.

\section{Conclusion}

Higher education institutions should overcome their fascination with new technologies, especially mobile technologies, and make connections between what is required in teaching and learning, and what can practically be provided by new technologies. However, institutions should also not be suspicious about the mobile technology, but instead see how this technology can be complementary to their current instructional model. These research results indicate that mobile applications can be used successfully on VUT Ekurhuleni campus to support teaching and learning. From the literature consulted in this paper it is evident that higher education environment has come to be more demanding in the past twenty years or so. Therefore, this has resulted in higher education institutions facing countless challenges. Academic leadership and management need to be an integrated collaborative effort that draws on the experiences and expertise of academics. Students are forever keen about experiencing using electronic communication more, especially since they do not need training and they are already familiar with and using it. In conclusion, future research may focus on the readiness of lecturers to use m-learning to support teaching and learning, and the effectiveness of connectivism as a learning framework.

\section{References}

Alley, M. (2008). Foundations of educational theory for online learning. In Anderson, $T$ (ed). The theory and practice of online learning. $2^{\text {nd }}$ ed. Athabasca: Athabasca University.

Al-Fahad, F. N. (2009). Students' attitudes and perceptions towards the effectiveness of mobile learning in King Saude University. Turkish online Journal of education technology, 8, 111-119.

Brown, T. (2005). Towards a model for m-learning in Africa. International Journal on e-learning, 2(1).

Coates, S. (2005). The value of student engagement for higher education quality assurance. Quality in Higher Education, 11(1), 25-36.

Duff, S. (2013). An update on South Africa's most popular Social Networks. [Online] http://www.blog.webafrica.co.za. 
Duncan-Howell, J. \& Lee, K. T. (2007). M-Learning: Finding a place for mobile technologies within tertiary education settings. In ICT: Providing choices for learners and learning. Proceedings ascilite Singapore 2007. [Online] http://www.ascilite.org.au/conference/singapore07/procs/duncanhowell.pdf.

Gilbert, J., Morton, S. \& Rowley, J. (2007). E-learning: the student experience. British journal of education technology, 3, 141-152.

Goh, T. \& Kinshuk, D. (2006). Getting Ready For Mobile Learning - Adaptation Perspective. Journal of Educational Multimedia and Hypermedia, 15(2), 175-198.

Granic, A., Mifsud, C. \& Cukusic, M. (2009). Design, implementation and validation of Europe-wide pedagogical framework for e-learning. Computer and Education, 53, 1052-1081.

Green, H. \& Hannon, C. (2007). Their Space: Education for a digital generation. Onlinehttp://www.demos.co.uk/files/their\%20space\%20-\%20web.pdf

Kantore, A. (2011). User-Interface Evaluation Metrics for a typical M-Learning Application. Magister Technologiae dissertation, Nelson Mandela Metropolitan University (NMMU): South Africa.

Kift, S., Nelson, K. \& Clarke, J. (2010). Transition Pedagogy: A third generation approach to FYE- A case study of policy and practice for the higher education sector. The international Journal of the First Year in Higher Education, 1(1), 1-20.

Kuh, G. (2007). What matters to student success in the first year of university? Keynote address at the $10^{\text {th }}$ Pacific Rim First Year Experience in Higher Education Conference, "Regenerate-EngageExperiment". $\quad$ Brisbane, Australia. [Online]http://www.fyhe.com.au/past_papers/papers07/fullprogram2.html.

Ling, R. (2008). New tech, new ties: how mobile communication is reshaping social cohesion. Cambridge, MA: M IT press.

Matli, W., Conradie, P. \& Sibiya, P. (2013). The use of Social Network Applications as an Educational supporting tool at Vaal University of Technology Ekurhuleni Campus, RSA. Proceedings of the $18^{\text {th }}$ World Conference on Co-Operative \& Work-Integrated Educated. Durban, South Africa. [Online]http://www.waceinc.org/durban2013/NonRefereed\%20Papers/South\%20Africa/Walt er\%20Matli\%20Vaal\%20University\%20of\%20Technology.pdf.

Nicholson, S., Maclaod, H. \& Haywood, J. (2005). E-learning; who is leading whom, and where might the road be going? $3^{\text {rd }}$ International Conference on Universal Access in Human Computer Interaction (UAHCI).

Oblinger, D.G. \& Oblinger, J. L. (2005). Education The Net Generation: Educause e-book publication. [Online]http://www.educause.edu/ir/library/pdf/pub7101.pdf.

Ramanau, R., Hosein, A. \& Jones, C. (2010). Learning and Living Technologies: A longitudinal Study of First Year Students' Expectations and Experiences in the Use of ICT. $7^{\text {th }}$ International Conference on Networked Learning.

Resources, I. (2006). Industry resources: Text messaging. [Online] http://www.corporate.smsac/industryresources/text_messaginng.htm .Accessed 08 March 2013.

Robertson, C. (2001). What's the outcome? LINK 2, October. LTSN for hospitality, Leisure, sport and tourism.

Schroer, W. J. (2013). The social librarian: Generation $\mathrm{x}, \mathrm{y}, \mathrm{z}$ and others cont'd. [Online] http://www.socialmarketing.org/newsletter/features/generation3.htm.Accessed 07 February 2013.

Siemens, G. (2004). Connectivism: A learning theory for the digital age, [Online] http://www.elearnspace.org/articles/connectivism.htm .Accessed 08 March 2013.

Simuth, J. \& Sarmany-Schuller, I. (2012). Principles for e-pedagogy. Social and behavioural sciences, 46, 4454-4456.

Strydom, J. F., Basson, N. \& Mentz, M. (2010). Enhancing the quality of teaching and learning: using student engagement data to establish a culture of evidence. Publisher: Council of higher education SA.

Tapscott, D. (2009). Growing up Digital: How the Net Generation is Changing Your World. New York, NY: McGraw Hill.

Torii-Williams, E. (2004). Incorporating the use of E-mail into a language program. Computer assisted language learning, 17(1), 109-122.

Traxler, J. (2007). Defining, discussing and evaluating mobile learning. International review of research in Open and Long learning, 8(1), 1-12. 
Traxler, J. (2009). Current State of Mobile Learning. In M. Ally (Ed.), Mobile Learning: Transforming the Delivery of Education and Training (pp. 9-24). Athabasca: AU Press. [Online] http://www.aupress.ca/books/120155/ebook/99Z_Mohamed_Ally_2009-MobileLearning.pdf.

UNESCO Institute for Statistics. (2009). Guide to measuring Information and Communication Technology (ICT) in Education. Montreal: UNESCO-UIS. [Online] http://www.uis.unesco.org/template/pdf/cscl/ICT/ICT_Guide_EN.pdf.

Wagner, E. D. \& Wilson, P. (2005). Disconnected T+D, 59(12), 40-43.

Walton, M. (2009). Mobile literacies \& South African teens: Leisure reading, writing, and MXit chatting for teens in Langa and Guguletu. Cape Town: Shuttleworth Foundation. [Online] http://m4lit.files.wordpress.com/2010/03/m4lit_mobile_literacies_mwalton 20101.pdf.

Winters, N. (2006). What is Mobile Learning? In Big Issues in Mobile Learning: 'Introduction: Mapping the landscape of Mobile Learning.' University of Nottingham, Learning Sciences Research Institute. Nottingham: Learning Sciences Research Institute. [Online] http://www.lsri.nottingham.ac.uk/msh/Papers/BIG_ISSUES_REPORT_PUBLISHED.pdf.

World Wide Worx. (2010). Mobile internet booms in SA. [Online] http://www.worldwideworx.com/2010/05/27/mobile-internet-booms-in-sa/. 